UDC 576.89

\title{
NEW VIRGULID CERCARIA (TREMATODA, LECITHODENDROIDEA) FROM FRESHWATER MOLLUSK MELANOPSIS PRAEMORSA (MELANOPSIDAE) FROM AZERBAIJAN WATER BODIES. MORPHOLOGY AND CHAETOTAXY OF CERCARIA AGSTAPHENSIS 31
}

\author{
A. A. Manafov \\ Institute of Zoology NAS Azerbaijan Republic \\ Thoroughfare 1128, block 504, Baku, 1073 Azerbaijan \\ E-mail: asif_abbasoglu@mail.ru
}

Received 12 November 2009

Accepted 10 November 2011

\begin{abstract}
New Virgulid Cercaria (Trematoda, Lecithodendroidea) from Freshwater Mollusk Melanopsis praemorsa (Melanopsidae) from Azerbaijan Water Bodies. Morphology and Chaetotaxy of Cercaria agstaphensis 31. Manafov A. A. - An illustrated morphological description with chaetotaxy and differential diagnosis of a new virgulid cercaria - Cercaria agstaphensis 31 from the freshwater prosobranchial mollusk Melanopsis praemorsa (Linnaeus, 1758) are given. Special attention is paid to the arming of the tegument, structure of the glandular apparatus, excretory system, digestive system, structure of the sensory apparatus and other larval morphological characters.
\end{abstract}

Key words: virgule, chaetotaxy, Melanopsis praemorsa, Cercaria agstaphensis.

Новые виргулидные церкарии (Trematoda, Lecithodendroidea) из пресноводного моллюска Melanopsis praemorsa (Melanopsidae) из водоемов Азербайджана. Морфология и хетотаксия Cercaria agstaphensis 31. Манафов А. А. - Приводятся рисунки, описание морфологии, в том числе и хетотаксии, а также дифференциальный диагноз новой виргулидной церкарии - Cercaria agstaphensis 31 из пресноводного переднежаберного моллюска Melanopsis praemorsa (Linnaeus, 1758). Особое внимание уделено вооружению тегумента, строению железистого аппарата, экскреторной системы, пищеварительной системы, строению сенсорного аппарата и других индивидуальных особенностей организации стилетных виргулидных церкарий.

Ключевы е слова: виргула, хетотаксия, Melanopsis praemorsa, Cercaria agstaphensis.

Introduction

In the first and the second articles (Manafov, $2011 \mathrm{a}, \mathrm{b}$ ), along with pictures and descriptions of Cercaria agstaphensis 11 and Cercaria agstaphensis 27, the summary on some results of our longtime researches (1982-2008) was presented. Particularly, there were some notes on parthenitae and cercariae from the freshwater mollusk Melanopsis praemorsa (Linnaeus, 1758). In a short systematic review of the species we stated that in mollusks Melanopsis praemorsa from reservoirs in Azerbaijan, 41 species of trematode cercariae were found, of which 33 were studied and described for the first time, and 2 cercariae species were redescribed.

The majority of species found (23) belongs to the group Xiphidiocercariae or stiletto cercaria (order Plagiorchiida). Of them, 21 species belong to the morphological group Virgulae (superfam. Lecithodendroidea), and $2-$ without virgule, to the group Microcotylae. Order Heterophyida is represented by 7 species, order Schistosomatida - by 2 species (fam. Sanguinicolidae - 1; fam. Schistosomatidae - 1), order Strigeidida by 5 species (suborder Cyathocotylata -4 , and suborder Strigeata -1 species). Families Echinostomatidae, Notocotylidae and Philophthalmidae are represented by 1-2 species each. Many resistant nidi of metagonimosis, heterophyasis, opisthorchiasis, haplorchiasis, notocotylosis were revealed, and also presents potential for the outbreaks of schistosomiasis (as dermatitis form), phyilophthalmosis, etc. 
Cercaria agstaphensis 31, the larva described in this communication, is a typical exotic representative of lecithodendroid cercariae with three pairs of penetration glands and some individual features not found in other species of cercariae in the entire range of the first intermediate host - mollusk Melanopsis praemorsa.

\section{Material and methods}

Mollusks were collected from 1982 to 2008 in different water bodies of Azerbaijan (rivers Kura, Akstafachay, Dzhogaz, Kyurekchay; reservoirs Akstafa, Mingechaur, Varvara, Shemkir, Enikend; streams, springs, artesian waters, canals and other waterways of the South Slope of the Greater Caucasus and the north-eastern slope of the Lesser Caucasus). Totally, we have examined 96, 718 mollusks and found cercariae of 41 trematode species belonging to at least 11 families.

To identify the infected animals, collected mollusk were placed one by one into $25 \mathrm{~cm}^{3}$ glass vessels filled with water for 12-24 hours or more. Mollusks with cercariae were selected under binocular microscope MBS -1 . Morphology of parthenitae, cercariae and metacercariae was studied on living material of fully grown specimens. For this purpose, binocular microscopes MBI-3, MBI-15 with phase contrast were used. All drawings were made with the aid of the drawing device RA-4. To reveal sensillae in cercariae, the traditional method of silver nitrate impregnation (Ginetsinskaya, Dobrovolsky, 1963) and its various modifications (Alekperov, Manafov, 1995 ) were used. To analyze the chaetotaxy, Richard nomenclature (1971) was used with additions of Bayssade-Dufour (1979).

Measurements of parthenitae and larvae were carried out on material fixed in $4 \%$ formalin, and $3 \%$ silver nitrate solution. In each case, the measurement was made on 15 larvae.

The measurements were processed statistically: arithmetical mean $(\mathrm{M})$, mean quadratic deviation $(\mathrm{G})$, and coefficient of variation (CV) were calculated (Plokhinskiy, 1978). The error of infection prevalence $\left(\mathrm{m}_{\mathrm{p}}\right)$ was calculated for each water body (Petrushevski, Petrushevskaya, 1960).

First described species were assigned with the code name Cercaria agstaphensis with corresponding serial numbers by name of the Akstafachay River. One species found in the Kura River was named as Cercaria kurensis.

\section{Description of Cercaria agstaphensis 31}

The body of relaxed cercaria is elongated oval (table 1; fig. 1). While contracted, it becomes pyriform (fig. 1, $b$ ), the narrower posterior end is shortened, extending anterior end strongly bends to the ventral side. Oral end of abdominal sucker almost touches the stretching back oral sucker. Pocket-like invagination is formed between them (fig. 1, f). The tail is broad and massive, while contracted its length is less than half of the body length (table 1).

Oral sucker is large. Its diameter is twice as much as diameter of abdominal sucker. This suckers' ratio is kept in cercariae anesthetized by heating and fixed with silver nitrate.

Table 1. Measurements of Cercaria agstaphensis 31 Таблиц 1. Размеры Cercaria agstaphensis 31

\begin{tabular}{lc|c|c|c}
\hline \multicolumn{1}{c}{ Parameters } & $\begin{array}{c}\text { Size, mm } \\
(\mathrm{min}-\mathrm{max})\end{array}$ & $\begin{array}{c}\text { Median size, } \mathrm{mm} \\
(\mathrm{M})\end{array}$ & $\begin{array}{c}\text { Mean square deviation } \\
(\mathrm{G})\end{array}$ & $\begin{array}{c}\text { Coefficient of variation } \\
(\mathrm{CV})\end{array}$ \\
\hline Body length & $0.081-0.091$ & 0.087 & 0.003 & 3.45 \\
& $(081-0.86)$ & $(0.084)$ & $(0.001)$ & $(1.19)$ \\
Body width & $0.061-0.072$ & 0.068 & 0.004 & 5.88 \\
& $(0.047-0.055)$ & $(0.050)$ & $(0.003)$ & $(6.0)$ \\
Tail length & $0.029-0.043$ & 0.036 & 0.005 & 13.89 \\
& $(0.029-0.039)$ & $(0.034)$ & $(0.003)$ & $(8.82)$ \\
Diameter of oral & $0.026-0.030$ & 0.027 & 0.001 & 3.7 \\
sucker & $(0.038-0.042)$ & $(0.039)$ & $(0.001)$ & $(2.56)$ \\
Diameter of abdom- & $0.016-0.020$ & 0.018 & 0.001 & 5.56 \\
inal sucker & $(0.018-0.021)$ & $(0.020)$ & $(0.001)$ & $(5.0)$ \\
Stiletto & $0.014-0.016$ & 0.015 & 0.001 & 6.67 \\
& $(0.014-0.016)$ & $(0.015)$ & $(0.001)$ & $(6.67)$ \\
\hline
\end{tabular}

Note. Measurements of larvae fixed in $4 \%$ formalin are given without brackets, and in parentheses are the measurements for larvae fixed $3 \%$ silver nitrate.

Примечан ие. В таблице без скобок приведены результаты измерения личинок фиксированных в $4 \%$-ном формалине, а в скобках - в $3 \%$-ном нитрате серебра. 


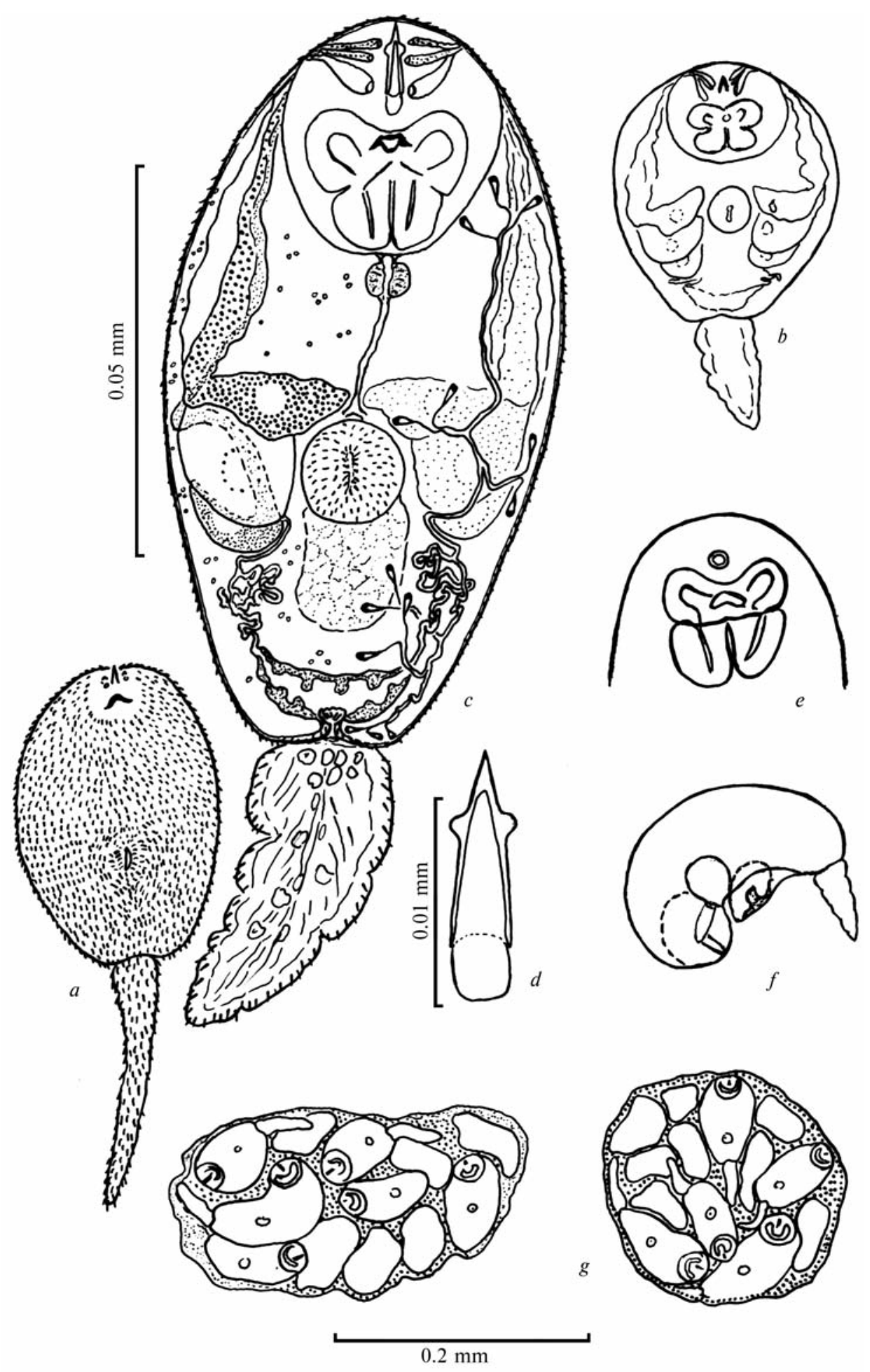

Fig. 1. Cercaria agstaphensis 31: $a$ - general view and larval armament; $b$ - body shape of shortened larva; $c$ - scheme of cercaria structure; $d$ - stiletto; $e$ - virgula; $\mathrm{f}$ - lateral view of shortened cercaria; $g-$ sporocysts.

Рис. 1. Cercaria agstaphensis 31: $a$ - общий вид и вооружение личинки; $b-$ форма тела сокращенной личинки; $c$ - схема строения церкарии; $d-$ стилет; $e-$ виргула; $f-$ боковой вид сокращенной церкарии; $g$ - спороцисты. 
When fixing in formalin, the ratio is changing. External opening of abdominal sucker is elongated in the longitudinal direction.

Integument of the larval body is armed with small spines. Their size increases a little toward the posterior end. The tail surface is completely armed with spines and their size increases toward the distal end. Ventral sucker is also armed with spines. Oral sucker has stiletto with length of less than $1 / 2$ diameter of sucker. Stiletto is thin-walled. Stiletto shoulders are seen very well. Stiletto stalk significantly expands and ends with large bulb.

Mouth opening is subterminal. It leads into narrow cavity with walls forming a medium-sized virgule with two massive blades (fig. 1,e). The blades are divided by obliquely arranged constrictions. There are slit-like lumens in posterior, narrower blade sections. In anterior, wider sections, it is wider. Buccal cavity leads into short prepharynx. Prepharynx opens into weakly muscular pharynx. Then narrow oesophagus reaches the anterior border of ventral sucker. Intestine bifurcation is directly in front of abdominal sucker. Branches of intestine are not possible to trace.

Three pairs of penetration gland cells are set in longitudinal rows at the body edges. Cells of the first pair of glands are elongated in transverse direction and almost contact in front of abdominal sucker. Their cytoplasm contains large, highly refractive granules of secretion. Relatively large cells of the second pair are located on each side of abdominal sucker and look optically empty. The smallest cells of the third pair are situated posterior to the second pair of the cells. They are crescent-like and elongated in transverse direction. Their ducts, in contrast to those of glands in the first and second pairs, start medially, and cross transparent glands dorsally going to the edge of the body. At the level of the first pair of the cells, they form characteristic loop-shaped twist and enter the common duct bundle. The secret in cells of the third pair is fine-grained, strongly refracting light. Ducts of all three pairs of the cells go to the anterior end in a common bundle. The ends of the ducts are greatly inflated with the largest cells in the second pair. The ducts of the first and third pairs of glands open at the bottom of stiletto, and highly inflated distal parts of the ducts of the second pair open closer to posterior end of stiletto. The location of glands and ducts are constant and varies little when larval body contracts.

Excretory formula: $2[(3+2+2)+(2+2+3)]=28$.

The anterior longitudinal collecting channels run along the inner edge of ducts of penetrating glands and reach the first pair of the cells, cross them near the duct's origin, run medially along the border between cells of the first and second pairs, and then turn back and cross cells of the second pair near the middle. Upon reaching the border between the cells of the second and third pairs, the ducts directed medially again round the cells of the third pair by the inner edge. The confluence of anterior and posterior collecting channels and balls of the main collecting channel are always behind the ventral sucker. The mutual arrangement of glands and canals of excretory system described above is highly constant.

Bladder is U-shaped. Excretory pore opens at the base of the tail.

Undifferentiated sexual bud in the form of dense cell mass is between the ventral sucker, main collective channels and the bladder.

Chaetotaxy is studied incompletely, in particular, there are no data on full composition of groups $\mathrm{St}_{1}, \mathrm{St}_{2}, \mathrm{StV}$, and lateral rows (fig. 2, $a, b$ ). However, some characteristic features are rather clear: no independent $\mathrm{StV}$ group, 2 sensillae in $\mathrm{CW}_{2}$ group, isolated AIL consisting of 3 sensillae, mixing of two pairs of ventral preacetabular sensillae in zones AIIV and AIIIV, and finally, three sensillae in the ventral postacetabular rows (fig. 2, $b$; table 2).

Larval parenchyma has few fat droplets.

Cercariae develop mostly in rounded sporocysts. Some saccular sporocysts were also found (fig. 1, g). Sporocyst sizes varied greatly. Diameter of round sporocyst was $0.21-0.25 \mathrm{~mm}$. Length of saccular sporocysts was $0.30-0.37 \mathrm{~mm}$, width $-0.17-0.19 \mathrm{~mm}$. 


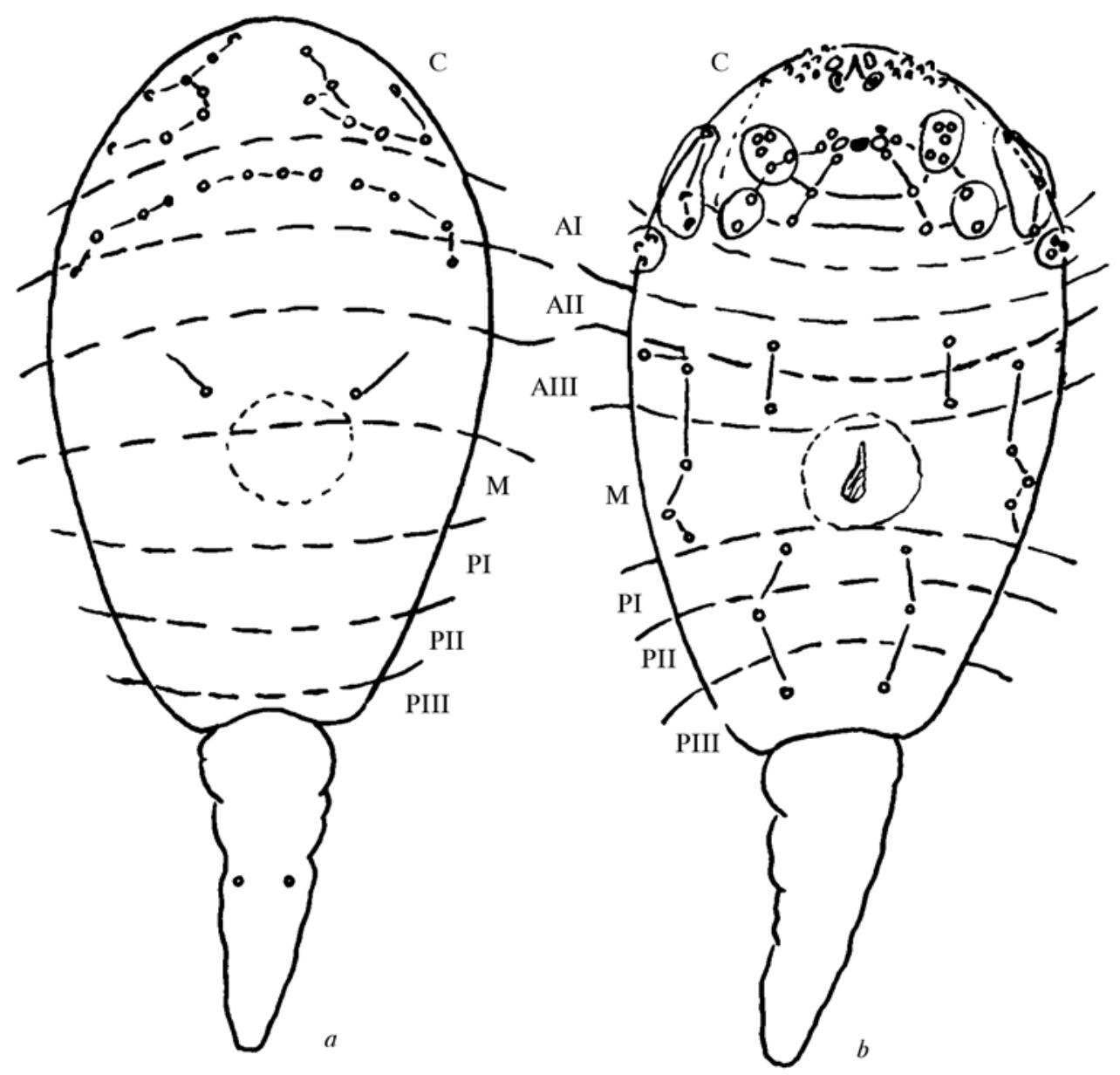

Fig. 2. Sensillae of Cercaria agstaphensis 31: $a$ - dorsal view; $b$ - ventral view.

Рис. 2. Сенсиллы Cercaria agstaphensis 31: $a$ - вид со спинной стороны; $b-$ вид с брюшной стороны.

Table 2. Description of sensillae arrangement in Cercaria agstaphensis 31.

Таблица 2. Описание расположения сенсилл Cercaria agstaphensis 31.

\begin{tabular}{|c|c|}
\hline $\begin{array}{l}\text { Head } \\
\text { Area of the mouth opening: } \\
3 \mathrm{CI}_{\mathrm{DL}}(1 \mathrm{CI} \mathrm{D}+2 \mathrm{CI} \mathrm{L}) \\
1 \mathrm{CII}_{\mathrm{I}} ; 5 \mathrm{C} \mathrm{II}_{2+3} \\
1 \mathrm{CIII}_{\mathrm{I}} ; 2 \mathrm{CIII} \mathrm{CIII}_{2} ; 3 \mathrm{CII}_{3} \\
\text { Stiletto area: } \\
\begin{array}{l}\text { (?) } \mathrm{StV} ; \quad \text { (?) } \mathrm{St}_{1} ; \quad \text { (?) } \mathrm{St}_{2} \\
6 \text { (7) } \mathrm{StDL}\end{array}\end{array}$ & 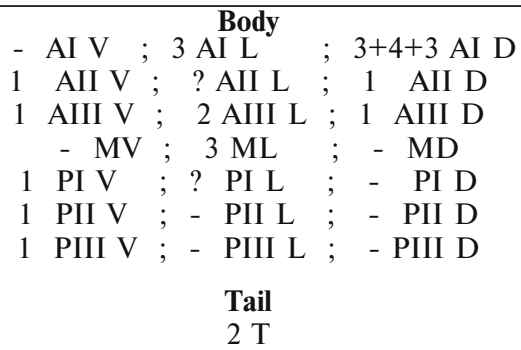 \\
\hline
\end{tabular}

Sporocyst wall is very thin. In the round and saccular sporocysts with mature cercariae we also found the embryos. Their number in one sporocyst could reach 25.

\section{Discussion}

The similar chaetotaxy makes us compare C. agstaphensis 31 with the previously described C. agstaphensis 11 (Manafov, 2011 a). From all larvae with "light" cells of the second pair of penetration glands, $C$. agstaphensis 31 differs by no granulation in these cells that are filled with transparent "hyaline" secret. 
There are significant differences in excretory formula. These two larvae differ by the structure of stiletto and the presence of small fat droplets in parenchyma of C. agstaphensis 31 .

C. indica $L X$ from mollusks Amnicola (fam. Bithyniidae, order. Discopoda) is very similar to $C$. agstaphensis 31 by the structure of penetration glands. This applies both to "hyaline" second pair of cells, and subtle distinctions in granulation of the cell secret in the first and third pairs. In general, they are rather close in size, but also there are significant differences. First of all, it concerns the tegument arming that is absolutely absent in the larva described by Sewall (1922). Stiletto in C. indica $L X$ is shorter than that in C. agstaphensis 31, smooth and has no shoulders.

Consequently, by up-to-date literary data, we could not identify larva described from Azerbaijan water bodies, therefore this allows consider C. agstaphensis 31 as an independent species.

The author expresses his deep gratitude to A. A. Dobrovolsky, Associate Professor, Department of Invertebrate Zoology, Biology and Soil Faculty, St. Petersburg State University, for valuable advice, direct assistance and support in the implementation of this work.

Alekperov I. H., Manafov A. A. A modified impregnation method and its advantages // Zool. zhurn. - 1995. 74, fass. 2. - P. 139-143. - Russian : Алекперов И. Х., Манафов А. А. Модифицированный метод импрегнации и его преимущества.

Ginetsinskaya T. A., Dobrovolsky A. A. A new method for detecting sensillae of trematode larvae and significance of these structures for systematics // Dokl. Akademii nauk USSR. - 151, N 2. - 460-463. Russian : Гинецинская T. А., Добровольский А. А. Новый метод обнаружения сенсилл личинок трематод и значение этих образований для систематики.

Manafov A. A. Fauna of parthenitae and cercariae of mollusk Melanopsis praemorza (L.) from northern Azerbaijan. - Moscow, 1990. - Dep. VINITI, N 4360 - Vol. 90. - 168 p. - Russian : Манафов А. А. Фауна партенит и церкарий моллюсков Melanopsis praemorza (L.) из Северного Азербайджана.

Manafov $A$. New virgulid cercaria (Trematoda, Lecithodendroidea) from mollusc Melanopsis praemorsa (Melanopsidae) from Azerbaijan water bodies. Morphology and chaetotaxy of Cercaria agstaphensis $11 / /$ Vestnik zoologii. - 2011. - 45, N 2. - P. 105-111.

Manafov A. New virgulid cercaria (Trematoda, Lecithodendroidea) from freshwater mollusc Melanopsis praemorsa (Melanopsidae) from Azerbaijan water bodies. Morphology of Cercaria agstaphensis 27 // Vestnik zoologii. - 2011. - 45, N 5. - P. 387-392.

Petrushevsky G. K., Petrushevskaya M. G. Reliability of quantitative indicators in the study of fish parasite fauna // Parazitol. collection. Zool. Institute. - Moscow : Nauka, 1960. - N 19. - P. 333-343. - Russian : Петрушевский Г. К., Петрушевская М. Г. Достоверность количественных показателей при изучении паразитофауну рыб.

Plokhinsky N. A. Mathematical methods in biology. Moscow : MGU, 1978. - 264 p. - Russian : Плохинский H. А. Математические методы в биологии.

Bayssade-Dufour Ch. L'appareil sensoriel des cercaries et la systematique des trematodes digenetiques // Mem. Mus. nat. hist. natur. Ser. A. Zool. $-1979 .-113 .-81$ p.

Richard J. La chetotaxie des cercaires. Valeur systematique et phyletique // Mem. Mus. nat. hist. natur. Ser. A. 1971. - 67. - 179 p.

Hall J. E. Studies on Virgulate Xiphidiocercariae from Indiana and Michigan // Amer. Midland Naturalist. 1960. - 63, N 1. - P. 226-245.

Hall J. E. , Groves A. E. Virgulate Xiphidiocercariae from Nitoris dilatatus Conrad // J. Parasitol. — 1963. 49, N 2. - P. 249-263.

Sewell R. B. S. Cercaria Indicae // Ind. J. Med. Res. - 1922. - 10, N 1. - 370 p. 